\title{
Application of denitrifying wood chip bioreactors for management of residential non-point sources of nitrogen
}

\author{
E. V. Lopez-Ponnada' ', T. J. Lynn², M. Peterson', S. J. Ergas' and J. R. Mihelcic ${ }^{1 *}$
}

\begin{abstract}
Two important and large non-point sources of nitrogen in residential areas that adversely affect water quality are stormwater runoff and effluent from on-site treatment systems. These sources are challenging to control due to their variable flow rates and nitrogen concentrations. Denitrifying bioreactors that employ a lignocellulosic wood chip medium contained within a saturated (anoxic) zone are relatively new technology that can be implemented at the local level to manage residential non-point nitrogen sources. In these systems, wood chips serve as a microbial biofilm support and provide a constant source of organic substrate required for denitrification. Denitrifying wood chip bioreactors for stormwater management include biofilters and bioretention systems modified to include an internal water storage zone; for on-site wastewater, they include upflow packed bed reactors, permeable reactive barriers, and submerged wetlands. Laboratory studies have shown that these bioreactors can achieve nitrate removal efficiencies as high as $80-100 \%$ but could provide more fundamental insight into system design and performance. For example, the type and size of the wood chips, hydraulic loading rate, and dormant period between water applications affects the hydrolysis rate of the lignocellulosic substrate, which in turn affects the amount and bioavailability of dissolved organic carbon for denitrification. Additional field studies can provide a better understanding of the effect of varying environmental conditions such as ambient temperature, precipitation rates, household water use rates, and idle periods on nitrogen removal performance. Long-term studies are also essential for understanding operations and maintenance requirements and validating mathematical models that integrate the complex physical, chemical, and biological processes occurring in these systems. Better modeling tools could assist in optimizing denitrifying wood chip bioreactors to meet nutrient reduction goals in urban and suburban watersheds.
\end{abstract}

Keywords: Eutrophication, Green infrastructure, Low impact development (LID), On-site wastewater treatment, Best management practice (BMP), Biofilm, Septic systems, Stormwater, Decentralized treatment, Microbiology

\section{Background}

Discharge of excess nitrogen to coastal water bodies has led to increasing eutrophication and aquatic dead zones worldwide [1-3]. Managing the nitrogen cycle has been identified as a Grand Challenge by the U.S. National Academy of Engineering (NAE) [4] and imbalances in this cycle are recognized as having harmful effects on human health and the environment $[2,5]$. Significant advances have been made in improving biological nitrogen removal

\footnotetext{
* Correspondence: jm41@usf.edu

'Department of Civil \& Environmental Engineering, University of South Florida, 4202 E. Fowler Ave./ENB 118, Tampa, FL 33620, USA

Full list of author information is available at the end of the article
}

(BNR) processes to manage point sources of nitrogen [6]. However, non-point sources of nitrogen from residential areas, such as stormwater runoff and discharges from onsite wastewater treatment systems, are difficult to control due to their diffuse nature and highly variable flow rates and concentrations. Over the last four decades, these nonpoint sources have also become a larger percent of the overall nitrogen loading to many coastal waters $[1,3,7,8]$. For example, approximately 10 trillion gallons of untreated stormwater runoff end up in U.S. waterways, which are sources for water supply and recreation [9], and approximately 60 million people in the U.S. are currently served by on-site septic systems [10]. 
Denitrifying wood chip bioreactors are a viable management tool for control of non-point nitrogen sources in urban and suburban watersheds $[1,11,12]$. These bioreactors employ a submerged zone containing wood chips to promote denitrification [13, 14]. As shown in Fig. 1, the wood chips serve as both a microbial biofilm support and a source of dissolved organic carbon (DOC), which promotes a suitable environment for the growth of heterotrophic denitrifying bacteria [15]. The use of wood chips has been compared with other solid organic substrates for biological denitrification (e.g., maize cobs, wheat straw, green waste, sawdust) and have been found to be the most suitable for maintaining a steady $\mathrm{NO}_{3}^{-}$removal, limiting excessive DOC discharges and $\mathrm{N}_{2} \mathrm{O}$ emissions [16-19].

Denitrifying wood chip bioreactors are designed so stormwater or wastewater that enters the bioreactor encounters anoxic conditions that supports denitrification. An advantage of using a solid organic substrate in the bioreactor is that it eliminates the need to provide a liquid feed system for providing chemicals such as methanol, which can be an added expense and is difficult to handle, deliver, and store [6]. It is also an important and challenging task to supply the proper stoichiometric requirement of chemical inputs under dynamic loading conditions often observed in management of residential stormwater and on-site wastewater. Excessive input of organic substrate can result in carry-over of DOC to the effluent, while too little substrate can result in incomplete denitrification, both negatively affecting the environment [6]. Moreover, lignocellulosic materials are usually available at the local level, minimizing transportation costs. Other societal benefits associated with these nitrogen management technologies include reduced flooding, improved groundwater recharge, the potential for on-site reuse of treated water, incentives and credits to municipalities for increased nitrogen removal, and lower capital and operation and maintenance (O\&M) costs $[13,20]$.

Denitrifying bioreactors that employ a lignocellulosic wood chip media are a promising technology for treatment of non-point sources of nitrogen in residential areas. However, identification of key knowledge gaps has not yet been performed that could lead to transformative advances of this technology. Accordingly, the objective of this paper is to provide a critical review of the literature on denitrifying bioreactors employing wood chip media used to manage residential non-point sources of nitrogen, specifically applications for stormwater runoff and on-site wastewater treatment. Prior review articles have focused on the use of denitrifying wood chip bioreactors for treatment of agricultural runoff [17, 21-24]. Those studies informed, but were not the focus of this review. Furthermore, although lignocellulosic wood chips are used in a number of other environmental applications, including bioremediation of acid mine drainage [25], biological air pollution control systems [26, 27], and treatment of aquaculture wastewaters [28], these topics are not discussed here.

\section{Applications of denitrifying wood chip bioreactors}

As mentioned previously, in many residential areas, the two largest non-point sources of nitrogen are stormwater runoff and on-site wastewater [3, 29, 30]. Although the application and regulatory requirements for systems treating these sources are different, the denitrifying wood chip bioreactors used for both sources are similar in their design, operation and challenges. For example, both sources have highly variable influent flow rates, pollutant influent concentrations, and chemical forms of nitrogen (which includes ammonium $\left[\mathrm{NH}_{4}^{+}\right]$, nitrite $\left[\mathrm{NO}_{2}^{-}\right]$, nitrate $\left[\mathrm{NO}_{3}^{-}\right]$, dissolved organic $\mathrm{N}$ [DON] and particulate organic $\mathrm{N}[\mathrm{PON}]$ ). Because of seasonal variations in rainfall or household occupancy, these system experience long dormant periods, which can adversely impact microbial communities carrying out biological processes [31, 32]. This section thus describes denitrifying wood chip bioreactor configurations for managing these sources of nitrogen.

\section{Biofiltration systems for treatment of stormwater runoff}

Sources of nitrogen in residential stormwater runoff include fertilizer from lawns, atmospheric deposition from

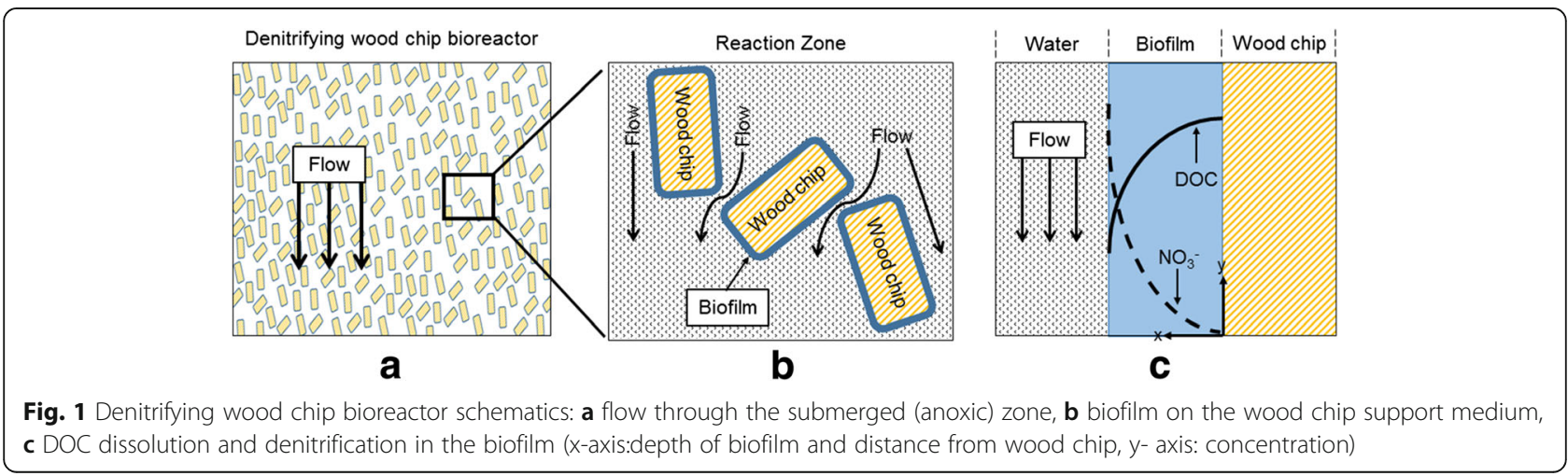


stationary and mobile combustion sources, soil, pet waste, and other organic debris [33, 34]. Nitrogen concentrations and species in residential runoff vary because of regional and environmental factors such as climate, land use, housing density, and the distribution of air pollution nitrogen sources [35]. Typical total nitrogen (TN) concentrations in U.S. stormwater runoff are reported to be $2.0 \mathrm{mg} \mathrm{N} / \mathrm{L}$ [36]. However, based on land use considerations, TN concentrations can range from $1.0 \mathrm{mg} \mathrm{N} / \mathrm{L}$ for landscapes that maintain wetland and forest features to $2.4 \mathrm{mg} \mathrm{N} / \mathrm{L}$ for landscapes that contain more impervious surfaces [37]. High-density residential areas also experience increases of TN in stormwater runoff to $11.6 \mathrm{mg} \mathrm{N} / \mathrm{L}$ during the dry season when nutrients have had time to accumulate on impervious surfaces [38].

Biofilters, biofiltration systems, and bioretention systems (Fig. 2) are similar technologies whose names are used interchangeably in the literature. These are considered a low impact development (LID) technology and structural best management practice (BMP) used for stormwater management. Figure 3 provides a timeline of the design and research advances for bioretention systems and shows that the introduction of woodchips The first bioretention manual came out in 1993 in Maryland [39] (Fig. 3). LIDs attenuate peak flows and improve the quality of stormwater runoff before it enters receiving groundwater and/ or surface water. LID technologies are designed to restore or preserve the natural hydrology of a site to before predevelopment conditions by working with the landscape, maintaining natural drainage courses, and reducing imperviousness [40, 41]. Structural LID technologies also include green roofs, permeable pavement, bioswales, and

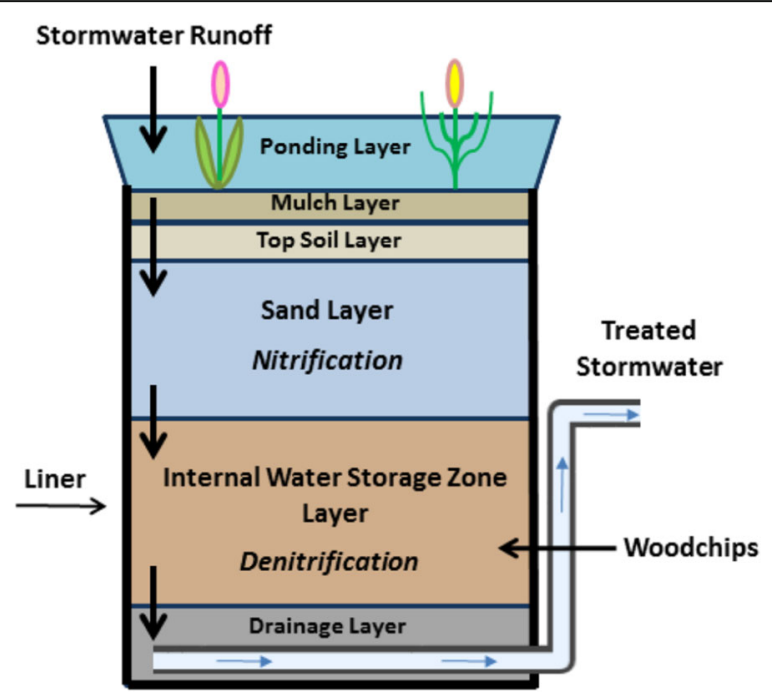

Fig. 2 Six distinct zones in a modified bioretention unit. Top to bottom shows regions of stormwater ponding, mulch, top soil, nitrification, denitrification (IWSZ) and drainage layers. Wood chips are contained in the denitrification (IWSZ) zone rainwater harvesting. Collins et al. [42] reviewed TN removal in eight types of stormwater control measures, including conventional and LID technologies (Table 1). In their study, they found that modified bioretention systems ranked highest for $\mathrm{TN}$ removal at 54.2\%, while green roofs and permeable pavement ranked lowest, at 7.4 and $-2.4 \%$ (TN export), respectively.

Bioretention systems typically include plants (Fig. 2), which promote uptake of nutrients, enhance microbial activity in the root zones and contribute DOC for denitrification [42-44]. A timeline showing the development of bioretention systems is provided in Fig. 3. The application of wood chips into an internal water storage zone (IWSZ) is a relatively new feature of these systems. Bioretention systems are relatively shallow depressions with a planting bed where stormwater runoff slowly infiltrates through different permeable layers such as vegetated soil, sand and gravel (Fig. 2). Conventional bioretention systems have been shown to achieve high removal efficiencies for suspended solids, organics, metals, and phosphorus through sedimentation, filtration, adsorption and plant and microbial uptake [23, 35]. However, a number of studies have shown poor TN removal, with an average of $25 \%$ (Table 1), and at times the effluent $\mathrm{TN}$ concentrations have been reported to exceed the influent concentrations [1, 42]. This is because conventional bioretention systems typically operate under unsaturated down flow hydraulic conditions, which promotes an aerobic environment. Under these conditions, $\mathrm{NH}_{4}^{+}$is oxidized to $\mathrm{NO}_{2}^{-}$and $\mathrm{NO}_{3}^{-}$via nitrification and exported with the effluent [1]. Dissolved organic nitrogen that leaches from the system may also originate from mulch, compost, soil or decaying plant matter $[35,45]$.

Although, nitrogen removal efficiencies for conventional bioretention systems studied at the laboratory and pilotscale are reported to range from $50-75 \%$ for total Kjeldahl nitrogen (TKN) and $60-80 \%$ for $\mathrm{NH}_{4}^{+}$[33], the export of $\mathrm{NO}_{2}^{-}+\mathrm{NO}_{3}^{-}\left(\mathrm{NO}_{\mathrm{x}}\right)$ and DON often negates the more effective removal of $\mathrm{PON}$ and $\mathrm{NH}_{4}^{+}$[33]. For example, a net export of $630 \%$ of $\mathrm{NO}_{\mathrm{x}}-\mathrm{N}$ [46] was reported for a conventional bioretention system with organic material placed in the top layers and another laboratory study reported a net export of $204 \% \mathrm{NO}_{3}^{-} \mathrm{N}$ [47] for a conventional bioretention with plants and shredded hardwood bark as mulch. The National Pollutant Removal Performance Database reports median $\mathrm{NO}_{\mathrm{x}}$ and $\mathrm{TN}$ removal efficiencies for field studies of conventional bioretention systems of only 43 and $46 \%$, respectively [48].

The highly variable $\mathrm{TN}$ removal efficiencies observed in conventional bioretention systems led to the development of modified biofilters or modified bioretention systems (previously shown in Fig. 2). Kim et al. [16] first proposed a modification of a conventional biofiltration 


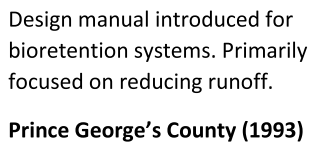

Laboratory study using batch, column, and experimental bioretention shows "Moderate reductions of TKN, ammonium, and phosphorus levels were found... Little nitrate was removed, and nitrate production was noted in several cases."

Davis et al. (2001)
Bioretention introduced as a Low-Impact
Development Integrated Management Practice. "The
low-impact development (LID) approach combines a
hydrologically functional site design with pollution
prevention measures to compensate for land
development impacts on hydrology and water
quality...also can be aesthetically pleasing."
Prince George's County (1999)

First bioretention laboratory study focused on nitrate removal that utilized wood chips as carbon source for denitrification and included an internal water storage zone (IWSZ).

Kim et al. (2003)
"In the past 15 years, bioretention has become one of the most popular storm-water BMPs in the United States and is now a key component of the LID storm-water management philosophy... Nonetheless, this technology is still immature and additional research is needed to provide quantitative design and performance information. " Davis et al. (2009)
Modeling of nitrate removal in denitrifying bioreactor and simulating various processes and mechanisms responsible for denitrification.

Deng et al. (2012)
Field scale study of modified \& conventional bioretention with an IWSZ and eucalyptus woodchips and gravel.

Lopez et al. (2016)

First denitrifying biofilters laboratory microcosms of an wood chips) used to compare $\mathrm{NO}_{3}{ }^{-}$removal performance under varying environmental conditions and to estimate the longevity of carbon media. Lynn et al. (2015)

First field scale modified bioretention using wood chips as carbon source in IWSZ treating dairy farm runoff.

Ergas et al. (2010) 2010 
Table 2 Field studies focused on removal of dissolved nutrients from stormwater and agricultural runoff with a modified bioretention system (adapted from LeFevre et al. [1])

\begin{tabular}{|c|c|c|c|c|c|}
\hline Study \# & Location & Carbon Source for Modified System & Lined & U.S. Climate Regions defined by NOAA & Reference \\
\hline 1 & Maryland & Shredded newspaper & Yes & Northeast & [102] \\
\hline 2 & North Carolina & $\begin{array}{l}\text { Not specified. Assuming organic material in } \\
\text { fill soil media }\end{array}$ & Yes & Southeast & [103] \\
\hline 3 & Maryland & Shredded newspaper & Not specified & Northeast & [104] \\
\hline 4 & North Carolina & $\begin{array}{l}\text { Not specified. Assuming organic material in } \\
\text { fill soil media }\end{array}$ & No & Southeast & [105] \\
\hline 5 & North Carolina & Assuming organic material in fill soil media & No & Southeast & [106] \\
\hline 6 & Connecticut & Wood chips (maple and birch wood) & Yes & Northeast & [23] \\
\hline 7 & Florida & Wood chips (eucalyptus wood) & Yes & Southeast & [52] \\
\hline
\end{tabular}

studies have used wood chips at the field scale ([23, 52]: Table 2). Additional field studies are necessary to provide design guidance for implementing modified bioretention systems in different climate zones (e.g., arid, sub-tropical and tropical), with different seasonal sunlight and precipitation patterns, and with different native and common ornamental plants and locally available lignocellulosic materials.

\section{Denitrifying wood chip bioreactors for on-site wastewater treatment}

On-site wastewater is also referred to as domestic wastewater, residential wastewater, domestic sewage, or a combination of these terms. For simplicity, the term residential wastewater is used here and refers to all the wastewater collected from a residence including water from toilets, showers, kitchen sinks and laundry. Conventional on-site residential wastewater treatment systems consist of a septic tank for solids separation followed by a soil infiltration system (or drain field), which provides further biological treatment and some pathogen removal. Advantages of on-site wastewater treatment include their simplicity of operation, low installation cost, low O\&M requirements and the ability to recharge local groundwater resources [53]. Major challenges of on-site wastewater treatment systems include siting restrictions in areas with a high groundwater table and proximity to drinking water sources and environmentally sensitive areas [54]. As discussed previously, on-site wastewater treatment systems are also subject to highly variable hydraulic and pollutant loading rates and long idle times (e.g., during vacations or seasonal use). In addition, these systems mainly depend on the homeowner to carry out or schedule required maintenance.

Most of the nitrogen in residential wastewater is in the form of PON, DON and $\mathrm{NH}_{4}^{+}$. Although nitrification is observed in aerobic regions of the drain field, conditions in conventional on-site wastewater treatment systems do not favor denitrification, resulting in $\mathrm{NO}_{3}^{-}$contamination of surface water and groundwater. Mechanical systems that require outside input of electricity that are similar to a centralized activated sludge BNR processes have been developed to improve nitrogen removal in on-site wastewater treatment systems. However, studies of these mechanical systems have shown inconsistent performance, with generally less than $60 \%$ TN removal, and problems due to the lack of $O \& M$ requirements by homeowners [55-57].

Because of these challenges, "passive" BNR systems have been developed for on-site wastewater treatment that are similar to conventional septic systems in their O\&M requirements [58]. Figure 4 shows an example of a passive on-site wastewater BNR system. Nitrification takes place in the first stage, which consists of an unsaturated trickling filter containing sand, expanded clay, gravel or zeolite media [59]. Denitrification takes place in a second stage, which consists of a packed bed reactor containing a "reactive" medium, such as wood chips [60] or elemental sulfur pellets [61]. Recirculation of effluent from the trickling filter back to the septic tank or a separate pre-anoxic tank is often used to dilute the influent to Stage 1 and reduce the influent $\mathrm{NO}_{3}^{-}$loading to Stage 2 [62]. Similar to modified bioretention systems that

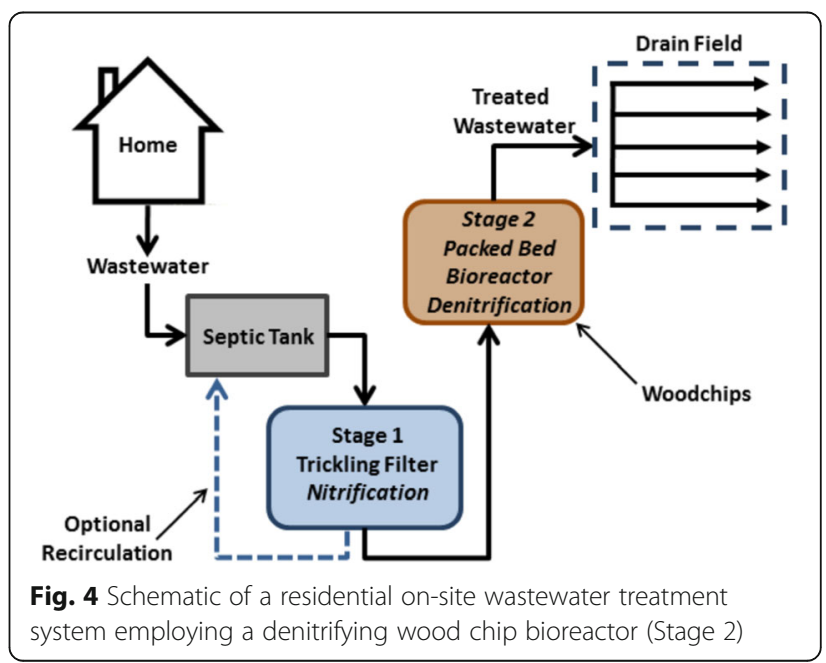


manage stormwater, submerged conditions are normally maintained in the wood chip reactor to favor the development of anoxic conditions while the reactive medium serves as both a microbial biofilm carrier and organic carbon substrate for denitrification (Fig. 1). Several of these systems are available commercially, including Nitrex $^{\text {tm }}$ (supplied by Lombardo and Associates, Newton, MA) and De-Nyte ${ }^{\circ}$ (supplied by Presby Environmental, Whitefield, NH) technologies. Other wood chip based denitrification technologies for on-site wastewater treatment include systems that combine nitrification and denitrification stages within a single unit [63], permeable reactive barriers (also called denitrification walls [64]) and horizontal or vertical flow wetlands containing wood chips $[65,66]$.

A timeline showing the development of wood chip bioreactors for on-site wastewater treatment is provided in Fig. 5. This timeline suggests the field performance of a wood chip bioreactor for on-site wastewater management is more advanced when compared to stormwater management. Lens et al. [31] carried out studies of treatment of unsettled wastewater in bench scale columns containing peat, bark and wood chip media. Approximately 38\% TN removal was observed with wood chips even though the systems were operated as aerobic percolation columns and were not specifically designed for denitrification. Another bench-scale study evaluated pine sawdust, sawdust mixed with soil, and wood chips/sand media for wastewater denitrification in horizontal-flow filters with 26 day empty bed contact times $(\mathrm{EBCT}=$ reactor volume/flow rate) [60]. In that study, the wood chip and sand mixture (1:1 ratio by volume) yielded the best $\mathrm{NO}_{3}^{-}$removal performance $(>97 \%)$. However, daily addition of sodium sulfite (a dissolved oxygen [DO] scavenger) was required to maintain anoxic conditions in the column. Nitrified residential wastewater was treated in a packed bed reactor containing a mixture of wood chips and sawdust [13], resulting in consistently low effluent $\mathrm{NO}_{3}^{-}$concentrations with little export of organic carbon. Tanner et al. [67] investigated five different treatment trains for on-site wastewater treatment and concluded that the best overall TN removal (95\%) was obtained when a recirculating vertical flow wetland with a sand medium was followed by a packed bed reactor containing wood chips. Rambags et al.
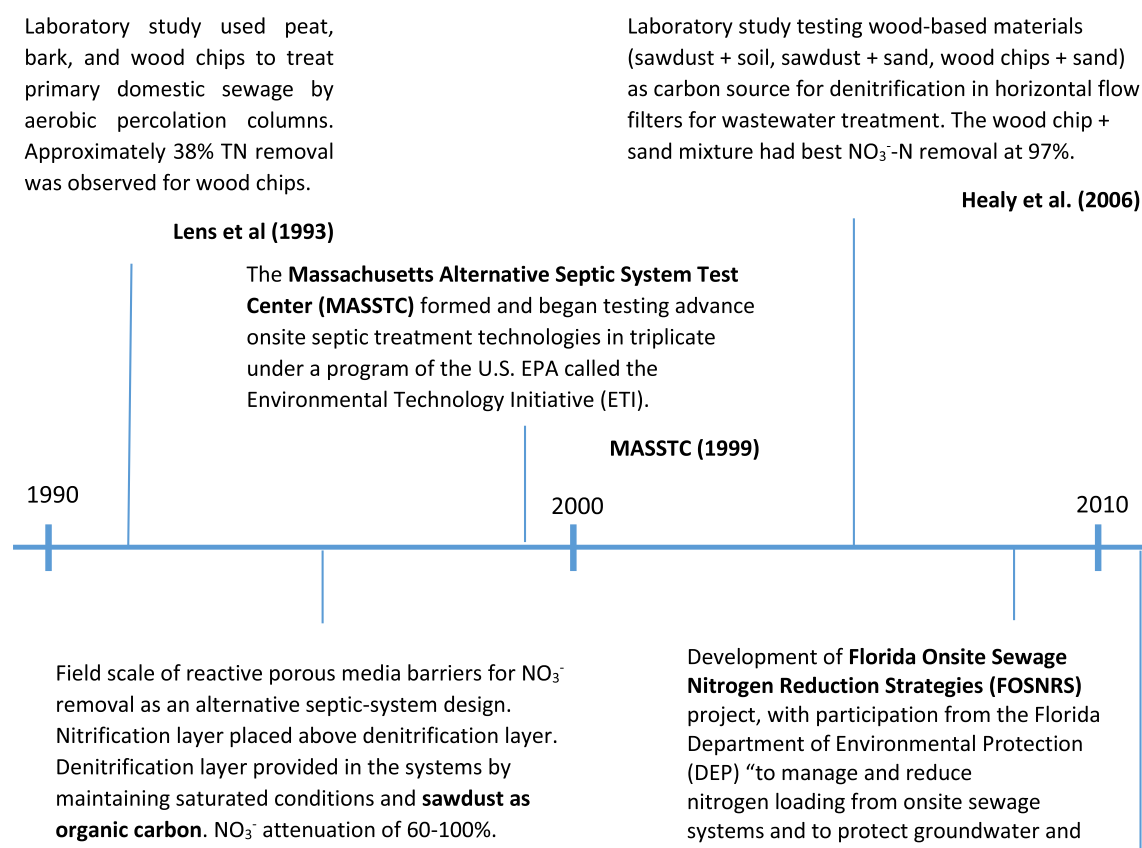

Healy et al. (2006)
Robertson and Cherry (1995)

dia barriers for $\mathrm{NO}_{3}$ Denitrification layer provided in the systems by maintaining saturated conditions and sawdust
Development of Florida Onsite Sewage Nitrogen Reduction Strategies (FOSNRS) project, with participation from the Florida Department of Environmental Protection (DEP) "to manage and reduce nitrogen loading from onsite sewage systems and to protect groundwater and surface waters."
MASSTC (1999)
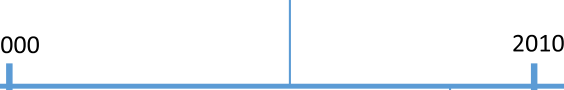

Full scale denitrifying wood chip bioreactor receiving secondary-treated septic effluent. System provided $\mathrm{NO}_{3}{ }^{-}$ removal of greater than $99.9 \%$.

Rambags et al. (2016)

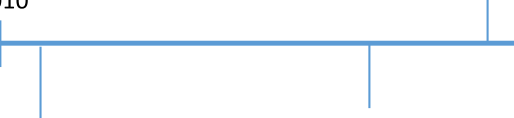

Development of passive nitrogen reduction technologies, and evaluation and prediction of the fate and transport of nitrogen from onsite sewage treatment and disposal systems using wood chips.

FOSNR Final Report (2015) 
[68] sampled a full-scale wood chip denitrifying bioreactor receiving secondary-treated septic tank effluent. Greater than $99.9 \%$ removal of $\mathrm{NO}_{3}^{-}$was observed, along with high removal efficiencies for total suspended solids (TSS), fecal indicator bacteria and viruses; however, removal of $\mathrm{NH}_{4}^{+}$, organic nitrogen, and phosphorus was inconsistent.

Several studies have investigated the use of permeable reactive barriers for on-site wastewater denitrification. In these systems, a permeable wall of wood chips is constructed in the subsurface downstream of the drain field to intercept the $\mathrm{NO}_{3}^{-}$contaminated groundwater plume. One study observed almost complete denitrification using this approach [64]. Additional studies have been carried out using horizontal flow, vertical flow, and hybrid wetlands systems containing wood chip media that might be useful to guide research for on-site wastewater management. For example, a hybrid wetland system was tested that consisted of a vertical flow wetland with wood chips, followed by a horizontal flow wetland with gravel and finally a vertical flow wetland with zeolite [65]. The observed removal of TN (72\%) was attributed to both high oxygen transfer for nitrification and organic carbon availability from the wood chips for denitrification. The same authors also compared hybrid systems consisting of vertical flow followed by horizontal flow wetlands with different types of media (gravel, wood chip and a gravel wood chip mixture) [69]. Improved TN removal performance was observed in the systems containing wood chips compared to the traditional system with only gravel, with $98 \% \mathrm{TN}$ removal in the vertical flow system [69].

\section{Process microbiology}

Nitrogen transformation processes that occur in denitrifying wood chip bioreactors include uptake of nitrogen by plants (assimilation) and microorganisms, nitrification, denitrification, dissimilatory reduction of nitrate to ammonia and anaerobic ammonia oxidation (ANAMMOX). Several studies have reported that dissimilatory reduction of nitrate to ammonia plays only a small role in $\mathrm{NO}_{3}^{-}$removal in denitrifying wood chip bioreactors $[18,22,70]$, while little research has been carried out on the role of ANAMMOX in these systems, therefore these processes are not discussed further. Because the electron donor for denitrification is primarily obtained from the wood chips, factors affecting the hydrolysis of lignocellulosic biomass are discussed here.

\section{Nitrogen transformation processes}

Nitrogen is an important macronutrient that is taken up from the soil and incorporated into plant and microbial biomass. Several studies have compared bioretention systems with and without plants and found that generally, systems with plants perform better at removing nitrogen than systems without plants [42, 44, 71, 72]. Studies have observed how plant species along with the organic content in the media of the bioreactor and the use of an IWSZ influence the variation of nitrogen removal. In some instances nitrogen leaching has occurred, attributed mainly to leaching of nitrogen from organic matter in the soil [71]. In addition, the presence of plants enhances microbial activity in the root zones, more aerobic conditions for nitrification and contributes DOC for denitrification [71, 73].

Both modified bioretention systems (Fig. 2) and denitrifying wood chip bioreactors for on-site wastewater treatment (Fig. 4) are often designed to include an unsaturated zone for nitrification prior to denitrification. Nitrification is an aerobic process, requiring sufficient DO for oxidation of $\mathrm{NH}_{4}^{+}$to $\mathrm{NO}_{2}^{-}$by ammonia oxidizing bacteria and archaea, followed by oxidation of $\mathrm{NO}_{2}^{-}$to $\mathrm{NO}_{3}^{-}$by nitrite oxidizing bacteria. Nitrification performance can be limited by low contact times at high hydraulic loading rates, washout of microorganisms (e.g., due to high shear forces), low temperatures, in low alkalinity waters, insufficient oxygen transfer to the nitrifying biofilm, and due to the presence of toxic organic compounds and metals [6]. For example, in a laboratory and field study of modified bioretention systems, nitrification appeared to limit TN removal, since $\mathrm{TN}$ and $\mathrm{NH}_{4}^{+}$concentrations were high yet $\mathrm{NO}_{3}^{-}-\mathrm{N}$ concentrations were below detection limits, indicating complete denitrification [23].

In denitrification, facultative microorganisms respire $\mathrm{NO}_{3}^{-}$or $\mathrm{NO}_{2}^{-}$under anoxic conditions [74]; therefore saturated conditions that limit oxygen transfer and promote the development of an anoxic zone are normally included in denitrifying wood chip bioreactors. A variety of electron donors can be used for denitrification including inorganic compounds, such as elemental sulfur [61] and dissolved organic carbon leached from the wood chips as shown in Fig. 1 [32, 75]. Denitrification normally proceeds through a series of four sequential steps $\left(\mathrm{NO}_{3}^{-} \rightarrow \mathrm{NO}_{2}^{-} \rightarrow \mathrm{NO}(\mathrm{g}) \rightarrow \mathrm{N}_{2} \mathrm{O}(\mathrm{g}) \rightarrow \mathrm{N}_{2}(\mathrm{~g})\right)$. A number of genera of denitrifying microorganisms, as well as some archaea and fungi, have been identified including Firmicutes, Actinomycetes, Bacteriodes, Aquifaceae, Proteobacteria Alphaproteobacteria, Betaproteobacteria, Gammaproteobacteria and Epsilonproteobacteria [76].

Production of $\mathrm{N}_{2} \mathrm{O}$ is a particular concern for BNR processes because it is a potent greenhouse gas and ozone-depleting compound. Studies of denitrifying wood chip bioreactors have shown that $\mathrm{N}_{2} \mathrm{O}$ emissions are lower or similar to $\mathrm{N}_{2} \mathrm{O}$ emissions from fertilized agricultural fields or systems using other organic carbon sources [77]. For example, only a small fraction of the $\mathrm{NO}_{3}^{-}$removed $(0.6 \%)$ from a full scale denitrifying wood chip bioreactor in Canada was emitted as $\mathrm{N}_{2} \mathrm{O} . \mathrm{N}_{2} \mathrm{O}$ emission rates were comparable to those reported for 
agricultural croplands and less than emissions from nitrogen polluted water bodies [77]. In the summer months, the denitrifying bioreactor acted as an $\mathrm{N}_{2} \mathrm{O}$ sink [77]. Grover et al. [78] reported that bioretention systems were only minor $\mathrm{N}_{2} \mathrm{O}$ sources. Although peak $\mathrm{N}_{2} \mathrm{O}$ emissions from a modified bioretention system were an order of magnitude greater than from a conventional system, concentrations were the same magnitude as fertilized irrigated lawns [78]. Additional research is needed on characterizing $\mathrm{N}_{2} \mathrm{O}$ emissions from denitrifying wood chip bioreactors used to treat on-site wastewater, specifically studies that provide greater insights into the mechanisms of $\mathrm{N}_{2} \mathrm{O}$ production under transient loading conditions, and denitrifying wood chip bioreactor designs that minimize $\mathrm{N}_{2} \mathrm{O}$ emissions. Methane $\left(\mathrm{CH}_{4}\right)$ emissions may also be a concern because it is a potent greenhouse gas. Although $\mathrm{CH}_{4}$ emissions for denitrifying wood chip bioreactors are reported as lower than for constructed wetlands, conventional wastewater treatment, and manure composting facilities [77].

Several studies have investigated the presence of nitrogen transforming genes involved in denitrification in wood chip bioreactors $[76,79,80]$. Chen et al. [68] quantified nitrifying and denitrifying genes in the sand (nitrifying) and mulch layers of a conventional bioretention system. The results showed that the quantity of nitrifying and denitrifying genes decreased as a function of media depth, possibly due to decreases in DOC availability with depth [68]. In denitrification beds treating agricultural runoff it was concluded that microbial denitrification was the primary mechanism for $\mathrm{NO}_{3}^{-}$removal due to the abundance of cytochrome nitrite reductase (nirS) or copper nitrite reductase (nirK) genes [18].

\section{Biodegradation of lignocellulosic material}

A general stoichiometric equation for denitrification using a simple carbohydrate $\left(\mathrm{CH}_{2} \mathrm{O}\right)$ as an electron donor can be written as:

$$
5 \mathrm{CH}_{2} \mathrm{O}+4 \mathrm{NO}_{3}^{-}+4 \mathrm{H}^{+} \rightarrow 2 \mathrm{~N}_{2}+5 \mathrm{CO}_{2}+7 \mathrm{H}_{2} \mathrm{O}
$$

The simple carbohydrate could be derived from natural organic solid substrates that include wood, compost, leaves, or soil organic matter [70]. Wood is primarily composed of lignocellulose that consists of cellulose (45-55\% content), hemi-cellulose (24-40\%) and lignin $(18-35 \%)$ [81, 82]. Cellulose is a glucose polymer with $\alpha$-1,4-linkages, hemicellulose is a heteropolysaccharide polymer and lignin is an amorphous heteropolymer $[82,83]$. Use of a solid substrate requires the additional step of hydrolysis to first solubilize the organic carbon [15]. Hydrolysis occurs when bacteria excrete extracellular enzymes that break down solid substrates into DOC that has a small enough molecular weight to pass (or dissolve) through the bacteria's cell membrane [84]. The rate of hydrolysis of hemicellulose is known to occur fastest, followed by cellulose and then lignin [83].

The biodegradation of cellulose, hemi-cellulose and lignin requires different enzymes and bacteria [84]. Cellulose is the most studied compound in mesophilic anaerobic environments, which is an expected operating environment for residential denitrifying bioreactors. Enzymes that depolymerize cellulose in these environments are organized in multi-enzymatic complexes called cellulosomes [85]. Enzymes found in cellulosomes are known to include endoglucanase, cellobiohydrolase and xylanase [86]. The products of cellulose depolymerization include cellobiose, cellodextrines and glucose, which can be metabolized in biofilms $[85,86]$.

Bacteria and fungi that are known to produce cellulosic hydrolytic extracellular enzymes have also been shown to exhibit other interesting capabilities that may be of importance in wood chip bioreactors [86]. Clostriduium cellulovorans is capable of utilizing other carbon sources found in wood, such as xylan (hemicellulose) and pectin [87]; the cellulosomes of Clostridium cellulolyticum are known to facilitate bacterial adhesion onto solid substrates [85]; in nitrogen-limited environments, Cellulomonas spp. can utilize $\mathrm{NH}_{4}^{+}$from solid cellulosic substrates for synthesis [88].

\section{Effect of transient loading conditions on microbial processes}

Differences have been observed in effluent water quality during start-up, operation, and dormant phases of denitrifying wood chip bioreactors. This may be due to the growth of microbial biofilms on the wood chips as the bioreactors mature with time or changes in the availability of different terminal electron acceptors [31]. During the start-up phase, denitrifying wood chip bioreactors have been reported in some instances to export high concentrations of DOC and TKN and remove only a small amount of $\mathrm{NO}_{3}^{-}$[32]. This may be due to the presence of aerobic conditions initially in the bioreactor. Higher rates of hydrolysis of lignocellulosic material are observed under aerobic compared with anaerobic conditions [83, 86, 89], resulting in more leaching of DOC and DON from the system $[32,90]$. In addition, performance is expected to improve as denitrifying biofilms are established in the reactors. The duration of the start-up phase for denitrification has been shown to be between six hours and one month [32]; however, the precise time-scale for start-up is unknown. Extended start-up periods are reported to be required for bioretention systems [23] and wastewater treatment systems [31] that included unsaturated zones for nitrification. Nitrifiers are slow growing autotrophs that require longer acclimation periods [6]. 
$\mathrm{NO}_{3}^{-}$removal rates increase as anoxic conditions are established, which facilitate the activity of denitrifying organisms [91]. In systems where both $\mathrm{DO}$ and $\mathrm{NO}_{3}^{-}$are present in the influent $[32,92]$ and a carbon source is available in excess, microbial communities will first utilize DO as an electron acceptor because it is more energetically favorable and then switch to $\mathrm{NO}_{3}^{-}$after $\mathrm{DO}$ is depleted below a certain level [74]. Lynn et al. [32] estimated an oxygen inhibition coefficient value for the Andrew's equation of $2.2 \mathrm{mg} / \mathrm{L}$ in a wood chip stormwater biofilter microcosm study.

During operation, excess DOC washes out of the bioreactor pore water as the influent water "mixes" with the water retained in the bioreactor pore water [32]. This decrease in pore water DOC results in decreased $\mathrm{NO}_{3}^{-}$ removal at high flow rates or longer periods of continuous operation [32]. At lower hydraulic loading rates, $\mathrm{NO}_{3}^{-}$removal rates increase as denitrifiers have more contact time to utilize $\mathrm{NO}_{3}^{-}$in the water.

During the dormant phase when the reactor is not receiving influent, $\mathrm{NO}_{3}^{-}$will become depleted, DOC concentrations will increase, oxidation reduction potential will decrease, and sulfate reduction can occur [24, 32, 77], resulting in odorous hydrogen sulfide production. Decreases in pore water DOC concentrations were observed after an extended dormant period (e.g., > 16 days) [32] possibly due to the growth of methanogens [77].

\section{Physical characteristics and operating conditions that impact design \& performance}

A number of factors influence the performance of denitrifying wood chip bioreactors including: (1) physical characteristics such as wood chip type and size and bioreactor depth; and (2) operating conditions such as hydraulic loading rate, hydraulic retention time (HRT), length of antecedent dry conditions, influent nitrogen concentration, temperature, other additives present in the media, media saturation and media longevity $[13,17$, 32, 93].

\section{Wood chip type and size}

The wood chip medium used in denitrifying wood chip bioreactors has been obtained from hardwood and softwood trees (Table 3). Hardwood trees have broader leaves and a higher carbon content and density than softwoods [94]. In general, observed $\mathrm{TN}$ removal rates are higher with softwood compared with hardwoods (Table 3). However, Peterson et al. [91] observed higher TN removals with the hardwoods Willow Oak and Red Maple than Virginia Pine softwood. These studies suggest that future research could determine the exact mechanism(s) that cause a particular wood chip type to influence the denitrification rate or long-term $\mathrm{NO}_{3}^{-}$removal performance. In addition, life cycle and economic assessments can assist our understanding of the environmental sustainability and cost of different materials.

Two studies evaluated the effect of wood chip size on the performance of denitrifying bioreactors [17, 91]. Cameron and Schipper [17] reported a slight increase in $\mathrm{NO}_{3}^{-}$removal efficiency with increasing wood chip size but the difference was statistically insignificant. Larger sized wood chips may contribute to higher porosity in the bioreactor greater internal pore structure that may lead to greater water holding capacity of a reactor. In contrast, Peterson et al. [91] found that $\mathrm{NO}_{3}^{-}$removal efficiencies were higher with smaller wood chip sizes. Smaller wood chips have a higher total surface area per unit mass, leading to more area for biofilms to grow (Fig. 1). However, smaller wood chips would be expected to also leach more TKN, which can offset some of the improvements in overall nitrogen removal [91]. The results from these studies demonstrate how wood chip size influences a number of other factors (e.g., porosity of the IWSZ, DOC leaching rates) that can play a role in increasing or reducing $\mathrm{NO}_{3}^{-}$removal rates. In addition, the contradicting results for nitrogen removal with wood chip size may be due to the higher influent $\mathrm{NO}_{3}^{-}$concentration used in the wastewater [17] compared to the stormwater study [91].

\section{Saturated zone depth}

The depth of the saturated zone can influence the performance of denitrifying biofilters for both stormwater and on-site wastewater treatment. Lynn et al. [7] studied denitrifying wood chip biofilters with varying depths that were operated with the same HRT. Greater $\mathrm{NO}_{3}^{-}$removal was reported in taller columns $(45$ and $60 \mathrm{~cm}$ ) compared to a shorter column $(30 \mathrm{~cm})$ at HRTs $\geq 3 \mathrm{~h}$. Tracer studies revealed that dispersion dominated transport was more pronounced in the shorter column. Similarly, a minimum IWSZ depth of $45 \mathrm{~cm}$ was reported by Zinger et al. [95] as optimal for TN removal. This same depth is included in the design depth recommendations by the Facility for Advancing Water Biofiltration [96]. This could potentially limit subsurface applications of denitrifying wood chip bioreactors in regions with high water tables or require larger overall volumes for shallower reactors. Thus, greater understanding is needed of the interplay between IWSZ depth, denitrification performance, and associated costs.

\section{Hydraulic loading rate}

In a similar way that an increase in column depth improves $\mathrm{NO}_{3}^{-}$removal due to longer HRT, a decrease in hydraulic loading rate can also increase retention time and improve $\mathrm{NO}_{3}^{-}$removal. Hydraulic loading rates for stormwater and on-site wastewater are naturally variable, but they can be reduced when incorporating flow 
Table 3 Collected data for nine different types of wood chips: type of study performed, carbon content, TOC leaching, influent and effluent nitrogen concentrations, and nitrogen removal

\begin{tabular}{|c|c|c|c|c|c|c|c|c|}
\hline & Wood Type & Type of Study & $\begin{array}{l}\text { Carbon Content } \\
(\%)\end{array}$ & $\begin{array}{l}\text { Leached TOC } \\
(\mathrm{mg} \mathrm{TOC} / \mathrm{L})\end{array}$ & $\begin{array}{l}\text { Influent Concentration } \\
\text { (mg N/L) }\end{array}$ & $\begin{array}{l}\text { Effluent Concentration } \\
\text { (mg N/L) }\end{array}$ & $\begin{array}{l}N \text { - Removal } \\
\text { (\%) }\end{array}$ & Reference \\
\hline \multirow[t]{9}{*}{ Softwood } & Pine & Column & 47 & 100 & 3 & 1.56 & 48 & {$[91]^{a}$} \\
\hline & Pine & Column & - & - & 15.8 & 11.1 & 30 & [18] \\
\hline & Pine & Column & 28 & 158 & 50 & $<2.0$ & 96 & [70] \\
\hline & Pine & Column & 28 & 175.3 & 50 & 17.7 & 65 & [70] \\
\hline & Pine & Column & 50 & - & 26 & 1.8 & 93 & [19] \\
\hline & Pine & Batch & 47 & - & 57.8 & 6.4 & 89 & {$[75]$} \\
\hline & Coniferous & Batch & 44 & - & 32.2 & 1.6 & 95 & [70] \\
\hline & Willow & Batch & 47 & 120 & 32.2 & 4.5 & 86 & [70] \\
\hline & Average & & $41.5(9.3)$ & $138.3(34.4)$ & 33.4 (18.7) & $5.84(5.8)$ & $75.2(24.9)$ & \\
\hline \multirow[t]{9}{*}{ Hardwood } & Eucalyptus & Column & 51 & - & 2.3 & $\mathrm{BDL}$ & 100 & {$[32,107]^{a}$} \\
\hline & Eucalyptus & Column & - & - & 15.8 & 9.9 & 37 & [18] \\
\hline & Maple & Column & 49 & 42 & 3 & 1.1 & 62 & [91] \\
\hline & Maple/Birch & Pilot & - & - & 7.6 & 0.9 & 88 & [23] \\
\hline & Red Gum & Batch & 44 & - & 55 & 7 & 87 & {$[75]$} \\
\hline & Wild Cherry & Column & 50 & 153 & 3 & 1.9 & 36 & [91] \\
\hline & Oak & Column & 50 & 41 & 3 & 1.2 & 62 & [91] \\
\hline & Beech & Column & 50 & 45 & 3 & 2 & 32 & [91] \\
\hline & Average & & $48.8(2.5)$ & $70.3(55.2)$ & $11.6(18.1)$ & 3.45 (3.6) & $63.0(26.6)$ & \\
\hline
\end{tabular}

Standard deviation (if applicable) is in parenthesis. BDL: below detection limit

a Study that reported ADC

control devices at the bioreactor outlet $[1,97,98]$. Lucas and Greenway [97] installed a regulated outlet in bioretention mesocosms, which increased the HRT from $15 \mathrm{~min}$ as free flow discharge to about $150 \mathrm{~min}$ when regulated. The authors observed up to 2.7 times greater $\mathrm{NO}_{\mathrm{x}}$ removal with increased retention time. Similarly for denitrifying bioreactors in the field, a regulated outlet control device could provide additional retention time for denitrification but additional ponding area storage capacity may be required if the influent flow rate is greater than the regulated effluent flow rate. For on-site wastewater, flow equalization or a decrease in water use within the household through more water efficient technologies or behavioral change could improve $\mathrm{NO}_{3}^{-}$removal.

\section{Intermittent conditions}

Intermittent loading conditions in denitrifying wood chip bioreactors are due to variations in nitrogen concentrations and diurnal fluctuations in residential water use and/or varying precipitation patterns associated with stormwater runoff. Intermittent operation constantly changes the biochemical processes that influence nitrogen transformation and DOC dissolution (Effect of transient loading conditions on microbial processes section). The impact of intermittent operational conditions in these systems in not well studied and should consider differences in physical, chemical and microbial processes that influence nitrogen removal performance during start-up, operation, and dormant phases.

\section{Longevity}

For practical application, the longevity of municipal denitrifying bioreactors is expected to be decades. Field studies performed on on-site wastewater treatment systems have reported appreciable denitrification activity after 15 years of operation [24, 99] and a microcosm study performed on stormwater denitrifying bioreactors estimated wood chip longevity of 21 years [7]. These findings fall within the estimated range of 9 to 72 years proposed for agricultural denitrifying bioreactors [14]. However, bioreactor saturation conditions may significantly affect bioreactor longevity. For example, a field study on agricultural denitrifying bioreactors observed increased wood chip degradation in an unsaturatedprone zone of a denitrification wall compared to a saturated-prone zone [21]. These results indicate that saturated conditions should be maintained to sustain the longevity of denitrifying wood chip bioreactors.

\section{Modeling of denitrifying wood chip bioreactors}

Although several studies highlight TN removal in denitrifying wood chip bioreactors used for stormwater 
runoff or on-site wastewater, few studies have developed quantitative models to assess the overall $\mathrm{TN}$ reduction effectiveness or guide future research. Without these models, TN load reduction design standards may be unreliable and the flexibility of the designer may be limited to dimensionally "fit" these systems into unique site characteristics. For example, during large storm events, much of the untreated stormwater runoff may by-pass the denitrifying bioreactor by overflowing from the ponding area. This large volume of untreated runoff may result in low overall TN reductions for the system regardless of TN removal efficiency of the bioreactor. Likewise for on-site wastewater treatment systems, if not sized properly for the incoming flow and volumes, the intended efficiency of nitrogen removal may not occur. When developed, these models could be applied to other wood chip denitrifying bioreactors such as permeable reactive barriers or biofilters used to remove $\mathrm{NO}_{3}^{-}$from agricultural runoff. Two challenges in developing these models is the accurate modeling of complex nitrogen transformation processes that occur at the biofilm-scale and integrating these models into watershed-scale hydrological modeling programs for groundwater transport (on-site wastewater) or surface water transport (stormwater).

Current models for stormwater management, such as the U.S. Environmental Protection Agency (EPA) Stormwater Management Model (SWMM), RECARGA, and DRAINMOD, focus more on the hydraulics and hydrology of the system rather than water quality. Two studies have however developed models that address water quality for denitrifying stormwater bioreactors. Deng et al. [100] developed a model for bioreactors containing different organic carbon amendments and included processes for dispersion, mass transfer of $\mathrm{NO}_{3}^{-}$into the biofilm, microbial growth, oxygen inhibition, DOC substrate limitation and temperature. This model may be useful for investigating $\mathrm{NO}_{3}^{-}$rate limiting factors that occur within microbial biofilms. A denitrification model that is compatible with SWMM version 5.1 has also been developed that can be used when designing stormwater management systems for land development projects [50]. The processes included in that model are wood chip dissolution and a denitrification kinetic model that incorporates DO and bioavailable DOC. This model may be useful for simultaneously evaluating water quality (e.g., $\mathrm{NO}_{3}^{-}$removal) and water quantity (e.g., runoff volume/rate reduction) goals based on a stormwater system design. Although the model predicted $\mathrm{NO}_{3}^{-}$removal within $10 \%$ of experimental results and is validated with a high Nash-Sutcliffe efficiency coefficient of 0.8 , it was recommended that the model be validated and calibrated with field data. These two denitrification models $[50,100]$ could also be improved by integrating a nitrification component to quantify $\mathrm{TN}$ load reduction effectiveness according to the specified use (e.g., on-site or stormwater) and bioreactor geometries. Advancement of knowledge on biological process within the different layers of denitrifying wood chip bioreactors can also improve modeling efforts to assist in watershed scale studies and the impact of implementing these systems at hotspots for nitrogen or sensitive ecosystems [11].

\section{Conclusions}

Denitrifying wood chip bioreactors can assist in removing nitrogen from non-point sources of residential pollution, such as stormwater runoff and on-site wastewater. The wood chip medium (a lignocellulosic substrate) provides a support structure for biofilms and the organic carbon source required for heterotrophic denitrifying bacteria that is essential for the transformation of reactive nitrogen to unreactive dinitrogen gas. Advantages of these passive systems are that they can handle the highly variable flow rates and nitrogen concentrations observed in stormwater runoff and on-site wastewater treatment. The use of a solid organic substrate obviates the need for liquid chemical feed systems and reduces the risk of carry-over of excess organic carbon into the effluent. Denitrifying wood chip bioreactors are considered appropriate technologies because they have minimal mechanical energy and chemical inputs and use plantbased and locally available materials such as wood chips, sand, and gravel. In addition, they provide benefits of groundwater recharge and opportunities for water reuse close to the site of wastewater generation.

Biofilters and bioretention systems that include an IWSZ containing wood chips achieve improved nitrogen removal from stormwater runoff than conventional BMPs. The performance of these systems depends largely on hydraulic and pollutant loading, which fluctuate with individual storm events and seasonal use and precipitation and thus is dependent on geographic location. However, little research has examined the performance of these systems under dynamic loading conditions in different climates, such as arid or tropical climates. With increasing changes in climate and more extreme weather events influencing precipitation and antecedent dry conditions, additional field studies that are linked to modeling will help understand the long-term performance and potential benefits of these systems [101].

A number of different denitrifying wood chip bioreactor process configurations have been successfully used to remove nitrogen from on-site wastewater, including packed bed reactors, permeable reactive barriers and submerged wetlands, with and without recirculation. Continuing long term studies on the dynamic performance of these systems would provide consistent and long-term nitrogen removal efficiency. Also, use of life 
cycle assessment and life cost analysis could assist efforts to quantify the economic and environmental tradeoffs between on-site nutrient removal versus expansion of sewers and centralized wastewater treatment systems for rural and suburban areas.

The type and size of the wood chips, hydraulic loading rate, and dormant period between periods of water application (e.g., during storm events or residential water use) have been shown to affect the hydrolysis rate of the lignocellulosic substrate, which affects the amount and bioavailability of DOC for denitrification. Maintaining saturated conditions during non-operational periods is also a critical design feature that controls the overall performance of denitrifying bioreactors. Higher $\mathrm{NO}_{3}^{-}$removal, lower TKN export and longer wood chip media longevity is expected from these designs compared with bioreactors that are only designed for saturation during operation. Future research could focus on understanding the interrelationships between bioreactor parameters and developing mathematical models and design tools that can be used to quantify water quality and quantity performance as a function of varying bioreactor designs and environmental conditions. Most studies of wood chip bioreactors have been performed on the individual performance of bench- or field-scale units rather than evaluating the impact of multiple systems on ground and surface water quantity and quality within a watershed. Lastly, incorporating life cycle assessments and life cost analysis studies on multiple systems can provide a holistic overview of the sustainability of implementing these systems at the watershed scale.

\section{Acknowledgements}

This material was made possible by the U.S. Environmental Protection Agency (EPA) grant 83556901, U.S. Dept. of Ed. GAANN PR/Award No: P200A090162, and NSF Florida-Georgia Louis Stokes Alliance for Minority Participation (FGLSAMP) Bridge to the Doctorate award grant number HRD $\# 1400837$. Its contents are solely the responsibility of the grantee and do not necessarily represent the official views of the USEPA. Further, USEPA does not endorse the purchase of any commercial products or services mentioned in the publication.

\section{Funding}

U.S. Environmental Protection Agency (EPA) grant 83556901

U.S. Dept. of Ed. GAANN PR/Award No: P200A090162

NSF Florida-Georgia Louis Stokes Alliance for Minority Participation

(FGLSAMP) Bridge to the Doctorate award grant number HRD \#1400837.

\section{Availability of data and materials}

Not applicable.

\footnotetext{
Authors' contributions

EL assisted in writing the Background, Applications of Wood Chip Denitrifying Bioreactors, and Physical Characteristics \& Operating Conditions Section, assisted in developing the figures/tables, and was a major contributor in writing this manuscript. TL assisted in writing the Process Microbiology and Applications of Wood Chip Denitrifying Bioreactors Sections, and was a major contributor in writing this manuscript. MP assisted in writing the Physical characteristics \& Operating Conditions, assisted in developing tables/figures, and was a major contributor in writing this manuscript. SJE developed the concept of the manuscript topic, assisted in
}

writing the Applications of Wood Chip Denitrifying Bioreactors Section, provided feedback in drafting this manuscript, and was a major contributor in writing this manuscript. JRM developed the concept of the manuscript topic, assisted in writing the Background Section and provided feedback in drafting this manuscript. All authors read and approved the final manuscript.

\section{Competing interests}

Not applicable.

\section{Consent for publication}

Not applicable.

Ethics approval and consent to participate

Not applicable.

\section{Publisher's Note}

Springer Nature remains neutral with regard to jurisdictional claims in published maps and institutional affiliations.

\section{Author details}

${ }^{1}$ Department of Civil \& Environmental Engineering, University of South Florida, 4202 E. Fowler Ave./ENB 118, Tampa, FL 33620, USA. Texas A\&M University-Kingsville, 700 University Blvd./MSC 213, Kingsville, TX 78363, USA.

Received: 14 October 2016 Accepted: 28 March 2017

Published online: 01 May 2017

\section{References}

1. LeFevre GH, Paus KH, Natarajan P, Gulliver JS, Novak PJ, Hozalski RM. Review of dissolved pollutants in urban storm water and their removal and fate in bioretention cells. J Environ Eng. 2015;141:04014050.

2. Braun, E. Reactive Nitrogen in the Environment Too Much or Too Little of a Good Thing. Paris: United Nations Environment Programme. WHRC; 2007.

3. USEPA. National management measures to control nonpoint source pollution from urban areas. 2005.

4. National Academy of Sciences. Grand Challenges for Engineering. In: National Academy of Engineering Summit Series - Face the Challenge National Academy of Engineering (NAE). 2008.

5. USEPA Science Advisory Board (SAB). Reactive Nitrogen in the United States: an analysis of inputs, flows, consequences, and management of options a report of the EPA science advisory board. pp. 140. Washington, D.C.: USEPA; 2011:140.

6. Ergas SJ, Aponte-Morales V. 3.8 - Biological nitrogen removal A2 - Ahuja, Satinder. In: Comprehensive water quality and purification. Waltham: Elsevier; 2014. p. 123-49.

7. Lynn TJ, Ergas SJ, Nachabe MH. Effect of hydrodynamic dispersion in denitrifying wood-chip stormwater biofilters. J Sust Water Built Environ. 2016; 2:04016004.

8. Butcher MR. Diffuse nutrient pollution from residential catchments. Graduate Theses and Dissertations. 2014.

9. Hobbs K, Garrison N. Rooftops to Rivers II: Green strategies for controlling stormwater and combined sewer overflows. pp. 100. New York: Natural Resources Defense Council (NRDC); 2011:135.

10. Septic Systems Overview. [https://www.epa.gov/septic/septic-systemsoverview]. Accessed 06 Oct 2016.

11. Liu J, Sample DJ, Bell C, Guan Y. Review and research needs of bioretention used for the treatment of urban stormwater. Water. 2014;6:1069-99.

12. Davis AP, Hunt WF, Traver RG, Clar M. Bioretention technology: overview of current practice and future needs. J Environ Eng. 2009;135:109-17.

13. Schipper LA, Cameron SC, Warneke S. Nitrate removal from three different effluents using large-scale denitrification beds. Ecol Eng. 2010;36:1552-7.

14. Christianson L. A practice-oriented review of wood chip bioreactors for subsurface agricultural drainage. Appl Eng Agric. 2012;28:861-74.

15. Chu L, Wang J. Denitrifcation performance and biofilm characteristics using biodegradable polymers PCL as carriers and carbon source. Chemosphere. 2013;91:1310-6.

16. Kim H, Seagren EA, Davis AP. Engineered bioretention for removal of nitrate from stormwater runoff. Water Environ Res. 2003;75:355-67.

17. Cameron SG, Schipper LA. Nitrate removal and hydraulic performance of organic carbon for use in denitrification beds. Ecol Eng. 2010;36:1588-95. 
18. Warneke S, Schipper LA, Matiasek MG, Scow KM, Cameron S, Bruesewitz DA, McDonald IR. Nitrate removal, communities of denitrifiers and adverse effects in different carbon substrates for use in denitrification beds. Water Res. 2011:45:5463-75.

19. Healy MG, Ibrahim TG, Lanigan GJ, Serrenho AJ, Fenton, O. Nitrate removal rate, efficiency and pollution swapping potential of different organic carbon media in laboratory denitrification bioreactors. Ecol Eng. 2012;40:198-209.

20. Oakley SM, Gold AJ, Oczkowski AJ. Nitrogen control through decentralized wastewater treatment: process performance and alternative management strategies. Ecol Eng. 2010;36:1520-31.

21. Moorman TB, Parkin TB, Kaspar TC, Jaynes DB. Denitrification activity, wood loss, and N 2 O emissions over 9 years from a wood chip bioreactor. Ecol Eng. 2010;36:1567-74.

22. Greenan CM, Moorman TB, Kaspar TC, Parkin TB, Jaynes DB. Comparing carbon substrates for denitrification of subsurface drainage water. J Environ Qual. 2006;35:824-9.

23. Ergas SJ, Sengupta S, Siegel R, Pandit A, Yao Y, Yuan X. Performance of nitrogen-removing bioretention systems for control of agricultural runoff. J Environ Eng. 2010;136:1105-12.

24. Robertson WD. Nitrate removal rates in woodchip media of varying age. Ecol Eng. 2010;36:1581-7

25. Becerra CA, López-Luna EL, Ergas SJ, Nüsslein K. Microcosm-based study of the attenuation of an acid mine drainage-impacted site through biological sulfate and iron reduction. Geomicrobiology. 2009;26:9-20.

26. Morgan-Sagastume JM, Noyola A, Revah S, Ergas SJ. Changes in physical properties of a compost biofilter treating hydrogen sulfide. J Air Waste Manage Assoc. 2003;53:1011-21.

27. Li H, Mihelcic JR, Crittenden JC, Anderson KA. Field measurements and modeling of two-stage biofilter that treats odorous sulfur air emissions. J Environ Eng. 2003;129:684-92.

28. Saliling WJB, Westerman PW, Losordo TM. Wood chips and wheat straw as alternative biofilter media for denitrification reactors treating aquaculture and other wastewaters with high nitrate concentrations. Aquac Eng. 2007; 37:222-33.

29. Carpenter SR, Caraco NF, Correll DL, Howarth RW, Sharpley AN, Smith VH. Nonpoint pollution of surface waters with phosphorus and nitrogen. Ecol Appl. 1998:8:559-68.

30. Poor ND, Cross LM, Dennis RL. Lessons learned from the Bay Region Atmospheric Chemistry Experiment (BRACE) and implications for nitrogen management of Tampa Bay. Atmos Environ. 2013;70:75-83.

31. Lens PN, Vochten PM, Speleers L, Verstraete WH. Direct treatment of domestic wastewater by percolation over peat, bark and woodchips. Water Res. 1994:28:17-26.

32. Lynn TJ, Yeh DH, Ergas SJ. Performance and longevity of denitrifying woodchip biofilters for stormwater treatment: a microcosm study. Environ Eng Sci. 2015;32:321-30.

33. Davis AP, Shokouhian M, Sharma H, Minami C. Water quality improvement through bioretention media: nitrogen and phosphorus removal. Water Environ Res. 2006;78:284-93.

34. Carey RO, Hochmuth GJ, Martinez CJ, Boyer TH, Dukes MD, Toor GS, Cisar $J$ L. Evaluating nutrient impacts in urban watersheds: challenges and research opportunities. Environ Pollut. 2013;173:138-49.

35. Li L, Davis AP. Urban stormwater runoff nitrogen composition and fate in bioretention systems. Environ Sci Technol. 2014;48:3403-10.

36. Schueler T. Impacts of impervious cover on aquatic systems. Ellicott City, MD, USA: Center for Watershed Protection; 2003.

37. Harper $\mathrm{HH}$, Baker DM. Evaluation of alternative stormwater regulations for southwest Florida. Environ Res Des. 2003.

38. Francey M, Fletcher TD, Deletic A, Duncan H. New insights into the quality of urban storm water in South Eastern Australia. J Environ Eng. 2010;136:381-90

39. County PGs. Design manual for use of bioretention in stormwater management. Landover: Prince George's County (MD) Government, Department of Environmental Protection Watershed Protection Branch; 1993.

40. Urban Runoff: Low Impact Development. [https://www.epa.gov/pollutedrunoff-nonpoint-source-pollution/urban-runoff-low-impact-development]. Accessed 06 Oct 2016

41. County PGs. Low-impact development design strategies: an integrated design approach. Prince George's County: Department of Environmenta Resources, Programs and Planning Division; 1999.

42. Collins KA, Lawrence TJ, Stander EK, Jontos RJ, Kaushal SS, Newcomer TA, Grimm NB, Ekberg MLC. Opportunities and challenges for managing nitrogen in urban stormwater: a review and synthesis. Ecol Eng. 2010;36: 1507-19.

43. Read J, Wevill T, Fletcher T, Deletic A. Variation among plant species in pollutant removal from stormwater in biofiltration systems. Water Res. 2008; 42:893-902.

44. Payne EGl, Pham T, Cook PLM, Fletcher TD, Hatt BE, Deletic A. Biofilter design for effective nitrogen removal from stormwater - influence of plant species, inflow hydrology and use of a saturated zone. Water Sci Technol. 2014;69:1312-9.

45. Hatt B, Deletic A, Fletcher T. Stormwater reuse: designing biofiltration systems for reliable treatment. Water Sci Technol. 2007:55:201-9.

46. Bratieres K, Fletcher T, Deletic A, Zinger Y. Nutrient and sediment removal by stormwater biofilters: a large-scale design optimisation study. Water Res. 2008:42:3930-40.

47. Davis AP, Shokouhian M, Sharma H, Minami C. Laboratory study of biological retention for urban stormwater management. Water Environ Res. 2001;73:5-14.

48. Center for Watershed Protection. National Pollutant Removal Performance Database. vol. 3. pp. 1-10: Center for Watershed Protection; 2007:1-10.

49. Hunt III WF. Pollutant removal evaluation and hydraulic characterization for bioretention stormwater treatment devices. Dissertation, Pennsylvania State University, PA, USA; 2003.

50. Lynn TJ, Nachabe, MH, Ergas SJ. Modeling denitrifying biofilters using SWMM5. J of Environ Eng. 2017. doi: http://dx.doi.org/10.1061/(ASCE)EE. 1943-7870.0001209.

51. Ahiablame LM, Engel BA, Chaubey I. Effectiveness of low impact development practices: literature review and suggestions for future research. Water Air Soil Pollut. 2012;223:4253-73.

52. Lopez EV, Lynn TJ, Peterson M, Ergas SJ, Trotz M, Mihelcic JR. Enhanced nutrient management of stormwater through a field demonstration of nitrogen removal in a modified bioretention system. In: World Environmental and Water Resources Congress. 2016. p. 60-9. http://dx.doi. org/10.1061/9780784479865.007.

53. Septic Systems Fact Sheet. Office of wastewater management decentralized wastewater program. Washington D.C: USEPA; 2008.

54. Florida department of health (FDOH). Standards for Onsite Sewage Treatment and Disposal Systems. In: Chapter 64E-6, Florida Administrative Code. FDOH ed. 2013.

55. Costa JE, Heufelder G, Foss S, Milham NP, Howes BL. Nitrogen removal efficiencies of three alternative septic system technologies and a conventional septic system. Environment Cape Cod. 2002;5:15-24.

56. Harden $\mathrm{H}$, Chanton J, Hicks R, Wade E. Wakulla county septic tank study: phase II report on performance based treatment system. In: Report to FDEP under agreement no WM926. Tallahassee: Florida State University, Dept. of Earth, Ocean and Atmospheric Science; 2010.

57. Roeder E, Chesna D, Terrill M, Ursin E, Brookman W. Florida Keys onsite wastewater nutrient reducing performance assessment: phase 3. Sampling protocol. 2009. [http://ww10.doh.state.fl.us/pub/bos/ResearchReports/ Wastewater\%20Sampling\%20Protocol\%20\%20Aug07_2009FINAL.pdf]. Accessed 04 Apr 2017

58. Hirst JE, Anderson DL, Smith DP: The Florida Onsite Sewage Nitrogen Reductions Strategies (FOSNRS) study: project overview and preliminary results. In: Florida Water Resources Conference. Orlando; 2013

59. Rodriguez-Gonzalez L, Payne K, Trotz M, Anderson D, Ergas SJ. Hybrid Adsorption and Biological Treatment System (HABiTS) for enhanced nitrogen removal in onsite wastewater treatment systems. In 13th IWA Specialized Conference on Small Water \& Wastewater Systems. Athens, Greece; 2016

60. Healy MG, Rodgers M, Mulqueen J. Denitrification of a nitrate-rich synthetic wastewater using various wood-based media materials. J Environ Sci Health Part A. 2006:41:779-88

61. Krayzelova L, Lynn TJ, Banihani Q, Bartacek J, Jenicek P, Ergas SJ. A tire-sulfur hybrid adsorption denitrification (T-SHAD) process for decentralized wastewater treatment. Water Res. 2014:61:191-9.

62. Sengupta S, Ergas SJ, Lopez EL. Investigation of solid-phase buffers for sulfuroxidizing autotrophic denitrification. Water Environ Res. 2007:79:2519-26.

63. St. Marseille J, Anderson B. Use of leaching chambers for on-site sewage treatment. Environ Technol. 2002:23:261-72.

64. Robertson WD, Cherry JA. In-situ denitrification of septic-system nitrate using reactive porous-media barriers - Field trials. Ground Water. 1995;33: 99-111. 
65. Saeed T, Sun GZ. Enhanced denitrification and organics removal in hybrid wetland columns: comparative experiments. Bioresour Technol. 2011;102: 967-74.

66. Fuchs VJ, Gierke JS, Mihelcic JR. Laboratory investigation of ammonium and nitrate removal in vertical flow regimes in planted and unplanted wetland columns. J Environ Eng. 2012;138:1227-30.

67. Tanner CC, Sukias JPS, Headley TR, Yates CR, Stott R. Constructed wetlands and denitrifying bioreactors for on-site and decentralised wastewater treatment: comparison of five alternative configurations. Ecol Eng. 2012;42: $112-23$.

68. Rambags F, Tanner CC, Stott R, Schipper LA. Fecal bacteria, bacteriophage, and nutrient reductions in a full-scale denitrifying woodchip bioreactor. J Environ Qual. 2016;45:847-54

69. Saeed T, Sun GZ. A comparative study on the removal of nutrients and organic matter in wetland reactors employing organic media. Chem Eng J. 2011;171:439-47.

70. Gibert O, Pomierny S, Rowe I, Kalin RM. Selection of organic substrates as potential reactive materials for use in a denitrification permeable reactive barrier (PRB). Bioresour Technol. 2008;99:7587-96.

71. Read J, Fletcher TD, Wevill T, Deletic A. Plant traits that enhance pollutant removal from stormwater in biofiltration systems. IntJ Phytoremediation. 2009;12:34-53

72. Palmer ET, Poor CJ, Hinman C, Stark JD. Nitrate and phosphate removal through enhanced bioretention media: mesocosm study. Water Environ Res. 2013;85:823-32.

73. Zhai X, Piwpuan N, Arias CA, Headley T, Brix H. Can root exudates from emergent wetland plants fuel denitrification in subsurface flow constructed wetland systems? Ecol Eng. 2013;61(Part B):555-63.

74. Madigan MT, Martinko JM, Parker J. Brock biology of microorganisms. Upper Saddle River: Prentice Hall; 1997.

75. Fowdar HS, Hatt BE, Breen P, Cook PL, Deletic A. Evaluation of sustainable electron donors for nitrate removal in different water media. Water Res. 2015;85:487-96.

76. Philippot L, Hallin S, Schloter M. Ecology of denitrifying prokaryotes in agricultural soil. Adv Agron. 2007;96:249-305.

77. Elgood Z, Robertson WD, Schiff SL, Elgood R. Nitrate removal and greenhouse gas production in a stream-bed denitrifying bioreactor. Eco Eng. 2010;36:1575-80.

78. Grover SPP, Cohan A, Chan HS, Livesley SJ, Beringer J, Daly E. Occasional large emissions of nitrous oxide and methane observed in stormwater biofiltration systems. Sci Total Environ. 2013;465:64-71.

79. Chen X, Peltier E, Sturm B, Young C. Nitrogen removal and nitrifying and denitrifying bacteria quantification in a stormwater bioretention system. Water Res. 2013;47:1691-700.

80. Zumft WG. Cell biology and molecular basis of denitrification. Microbiol Mol Biol Rev. 1997;61:533-616.

81. Betts WB, Dart RK, Ball AS, Pedlar SL. Biosynthesis and structure of lignocellulose. In: Betts WB, editor. Biodegradation: natural and synthetic materials. Berlin: Springer; 1991. p. 139-55.

82. Pérez J, Munoz-Dorado J, de la Rubia T, Martinez J. Biodegradation and biological treatments of cellulose, hemicellulose and lignin: an overview. Int Microbiol. 2002;5:53-63.

83. Malherbe S, Cloete TE. Lignocellulose biodegradation: fundamentals and applications. Rev Environ Sci Biotechnol. 2002;1:105-14.

84. Bruce ER, Perry LM. Environmental biotechnology: principles and applications. New York: McGrawHill; 2001. p. 400

85. Desvaux M. Unravelling carbon metabolism in anaerobic cellulolytic bacteria. Biotechnol Prog. 2006;22:1229-38.

86. Leschine SB. Cellulose degradation in anaerobic environments. Annu Rev Microbiol. 1995:49:399-426.

87. Kosugi A, Murashima K, Doi RH. Characterization of xylanolytic enzymes in Clostridium cellulovorans: expression of xylanase activity dependent on growth substrates. J Bacteriol. 2001;183:7037-43.

88. Young JM, Leschine SB, Reguera G. Reversible control of biofilm formation by Cellulomonas spp. in response to nitrogen availability. Environ Microbiol. 2012;14:594-604

89. Tomme P, Warren R, Gilkes N. Cellulose hydrolysis by bacteria and fungi. Adv Microb Physiol. 1995;37:1-81.

90. Sulaiman WRW, Lee ES. Pyrolysis of eucalyptus wood in a fluidized-bed reactor. Res Chem Intermed. 2012:38:2025-39.
91. Peterson IJ, Igielski S, Davis AP. Enhanced denitrification in bioretention using woodchips as an organic carbon source. J Sustain Water Built Environ. 2015;1:9.

92. Smith D. Sorptive media biofiltration for inorganic nitrogen removal from storm water. J Irrig Drain Eng. 2008;134:624-9.

93. Subramaniam D, Mather P, Russell S, Rajapakse J. Dynamics of nitratenitrogen removal in experimental stormwater biofilters under intermittent wetting and drying. J Environ Eng. 2015;142:04015090.

94. Ma F. Wood and timber. In: Salem press encyclopedia of science. 2015.

95. Zinger $Y$, Fletcher T, Deletic A, Blecken G, Viklander M. Optimisation of the nitrogen retention capacity of stormwater biofiltration systems. France: Lyon; 2007.

96. Facility for Advancing Water Biofiltration (FAWB). Adoption Guidelines for Stormwater Biofiltration Systems. Monash University; 2009. [http://www. monash.edu.au/fawb/products/index.html]. Accessed 06 Oct 2016.

97. Lucas WC, Greenway M. Hydraulic response and nitrogen retention in bioretention mesocosms with regulated outlets: Part II-Nitrogen retention. Water Environ Res. 2011:83:703-13.

98. Lucas WC, Sample DJ. Reducing combined sewer oeverflows by using outlet controls for green stormwater infrastructure: case study in Richmond, Virginia. J Hydrol. 2015;520:473-88.

99. Robertson WD, Vogan JL, Lombardo PS. Nitrate removal rates in a 15-yearold permeable reactive barrier treating septic system nitrate. Ground Water Monit Rem. 2008;28:65-72.

100. Deng Z, Sun S, Gang DD. Modeling nitrate-nitrogen removal process in firstflush reactor for stormwater treatment. Bioprocess Biosyst Eng. 2012;35:86574.

101. Coumou D, Rahmstorf S. A decade of weather extremes. Nat Clim Chang. 2012;2:491-6.

102. Hsieh CH, Davis AP. Multiple-event study of bioretention for treatment of urban storm water runoff. Water Sci Technol. 2005:51:177-81.

103. Hunt WF, Jarrett AR, Smith JT, Sharkey LJ. Evaluating bioretention hydrology and nutrient removal at three field sites in North Carolina. J Irrig Drain Eng. 2006;132:600-8

104. Davis AP. Field performance of bioretention: Water quality. Environ Eng Sci. 2007;24:1048-64.

105. Passeport E, Hunt WF, Line DE, Smith RA, Brown RA. Field study of the ability of two grassed bioretention cells to reduce storm-water runoff pollution. J Irrig Drain Eng. 2009;135:505-10.

106. Brown R, Hunt WF. Underdrain configuration to enhance bioretention exfiltration to reduce pollutant loads. J Environ Eng. 2011;137:1082-91.

107. Lynn TJ, Yeh DH, Ergas SJ. Performance of denitrifying stormwater biofilters under intermittent conditions. Environ Eng Sci. 2015;32:796-805.

\section{Submit your next manuscript to BioMed Central and we will help you at every step:}

- We accept pre-submission inquiries

- Our selector tool helps you to find the most relevant journal

- We provide round the clock customer support

- Convenient online submission

- Thorough peer review

- Inclusion in PubMed and all major indexing services

- Maximum visibility for your research

Submit your manuscript at www.biomedcentral.com/submit 